\title{
ARENA WATI AS A SHIP CAPTAIN: A TEXTUAL ANALYSIS OF MEMOIR ARENA WATI ENDA GULINGKU
}

Sohaimi Abdul Aziz

tgpenaga@yahoo.com

Fatiha Che Mat

tiehah_fatihah@yahoo.com

School of Humanities,

Universiti Sains Malaysia, 11800 USM, Penang, Malaysia.

Tel: +604-6536042.

\begin{abstract}
Arena Wati (1925-2009), is well-known by the Award of Malaysian National Laureate, which he received in 1988 for his outstanding contributions to the development of Malay literature. However he was also the captain of a sailing ship. His familial origins as sailors of Makassar, South Sulawesi, Indonesia have greatly influenced his writings. This article is a scrutiny of a work by Arena Wati in his capacity as a ship captain in relation to two functions, namely "as a trader" and "as a navigator". The approach to the text is through a qualitative content analysis, that is, interpretation and evaluation of messages associated with the text under study, namely, Arena Wati's memoir entitled Memoir Arena Wati Enda Gulingku (1991). Based on his successful implementation of both the functions mentioned, the analysis reveals that Arena Wati is an accomplished navigator. His knowledge of the maritime trade and the navigation he practiced establishes that Arena Wati's greatness as a ship captain is equal to his greatness as a fiction writer.
\end{abstract}

Keywords: ship captain, sailor, trader, maritime, navigator 


\section{INTRODUCTION}

The maritime history of Southeast Asia is very interesting. The maritime world is the world of sailing, shipping, seafaring and dock-related activities. Those who viewed the sea as a stage for travelling from one place to another were known as sailors and these sailors were probably also traders. The Makassar and Bugis sailors used sailing ships (or sail boats) such as schooners, pinisi, and padewakang (the biggest sailing vessel of trading and fishing and war fleets of South-Sulawesi) as mechanisms of transportation. Seafaring and docking activities were the stage for sailors, as well as their transportation to converge in vibrant social, economic and even political activities. Maritime Southeast Asia has existed for a long time. Its geographic conditions, vast and filled with thousands of islands, make Southeast Asia a busy, cosmopolitan maritime region for migration, communication and trade of diverse peoples.

A great deal of historical indications discovered prove that the history of maritime Southeast Asia began before B.C. Historical evidence such as pottery from Vietnam (the Sa-huynh-Kalanay civilization dated between 750-200 B.C.) may be found in many parts of Southeast Asia such as Thailand, Philippines, Malaysia and Indonesia (Shaffer, 1996:11). The formation of the MalayoPolinesian communities is the origin of the maritime history of Southeast Asia, better known as Nusantara (Archipelago). In the years of 4000 B.C., the migration of the Malayo-Polenesian communities began from Yunan in south China via the sea to the islands of Taiwan, and from Taiwan to the Philippines and east Indonesia. Between 3000 to 2000 B.C. these peoples moved via the sea to peninsular Southeast Asia (Shaffer, 1996:7). Among their modes of transportation were dugouts, sampan (indigenous small sailing vessel) and the sail boat. They settled in various places like estuaries and inland, and carried out diverse activities as farmers, fishermen, steel craftsmen, sailors and traders.

As Southeast Asia became known as Nusantara, expanding with small and large settlements, dynamic activities related to communication and trade began, not only among the thousands of islands in the region but also among economic and political powers, like the West, India and China. Southeast Asia became the link between the West and the East in a range of economic, political and cultural matters via the maritime trade that flourished with the use of boats and sail boats. Maritime trade refers to trading at coastlines and estuaries, in diverse forest products, spices, agilawood, sandalwood, resin and medicines. The harbours were centres for the collection and distribution of raw materials, buying and selling, storing commercial goods and stop-over venues for sailors and captains. 
In other words the maritime world of Southeast Asia grew rapidly in the past and continues to do so till today.

\section{ARENA WATI AND HIS MEMOIR}

Since the 16th century, maritime activity in Southeast Asia has been experiencing diverse challenges from social, economic and political turmoil. Western colonization such as the Portuguese, Dutch and English, the World War II and the Japanese Occupation, as well as local political unrest such as the Indonesian revolution, are among the many challenging events. However the maritime tradition of Nusantara continues to survive, sustained by sailors from Makassar like Arena Wati. Arena Wati, or Muhammad bin Abdul Biang or Andi Muhammad Dahlan bin Andi Buyong was born on 30 Julai 1925 in a district known as Kalumpang in Jeneponton, Makassar, Sulawesi Selatan, Indonesia. He was born of a seafaring ancestry. His father and grandfather were distinguished sailors and traders of Kalumpang. His grandfather, Abdul Fatah was from one of the four families from Kalumpang who owned large sail boats known as padewakang and his father owned a padewakang given the name of Samalewaya. They sailed to various parts of Nusantara. Arena Wati preserved their seafaring experience in his memoir. What is a memoir? According to Donald J.Winslow (1995:39) a memoir is:

A record of events, not purporting to be a complete history, but treating of such matters as come within the personal knowledge or within the memory of the writer, or are obtained from particular sources of information. The incidents recorded may come from a person's own life or from persons whom he knows or has known; an autobiographical record.

For Winslow, a memoir is the record of various events originating from a writer or someone known to the writer. The records may constitute his own memories or knowledge. He emphasizes that a memoir is more of a record of historical events or of a society that occured beyond oneself. A memoir lacks the aspect of the introspective journey of the writer into his self. In this regard, the memoir is less about the writer himself in comparison to the autobiography. Memoir Arena Wati Enda Gulingku conveys a meaningful message that lends itself to study through textual analysis. The textual analysis is supported by other texts applied as a supporting discipline which aids in the analysis, interpretation and evaluation of Arena Wati as a remarkable captain of a sailing ship. Among other texts is Gene Ammarell's book, which 
forms the term of reference in speaking of planetary navigation. In other words, the selected genre of the memoir will be studied through content analysis since it can explain further the connection between Arena Wati and his environment that is constructed from sailing, shipping and the ocean, the maritime world of Nusantara inherited since thousands of years ago. In addition, the memoir is connected to its writer's history, and therefore reconstructing Arena Wati's sailing history is actually reconstructing the history of a ship captain in the context of the maritime tradition of Nusantara.

\section{BEFORE BECOMING A WRITER}

Arena Wati obtained his early education in a Dutch school in Makassar, before it closed as a result of the war. Following that, at the young age of 17, in 1943, he became involved in the world of sailing and maritime trade. He made several voyages sailing and for maritime trade (trading via the sea) to several places in the Indonesian islands as well as in Singapore. He not only sailed but also travelled to Malaysia and obtained citizenship in Malaysia. Arena Wati inherited his seafaring and trading career from his father and grandfather. Since the age of 5 he became gradually exposed to the world of sailing and trading. He was introduced to trading on a small scale by his family when he learnt to sell confections in his village. In other words, trading on a small scale as a child of 5, Arena Wati became a young man with an aptitude for trade. Thus by the time he started sailing at the age of 17 he had two responsibilities, that is, sailing and trading. The experience in trading before he became a sailor is preserved in his memoir:

Enam bulan kemudian, tugas jual kuih ini semakin bertambah. Saya diasuh menjadi pedagang kecil. Kalumpang sebuah mukim yang mempunyai lebih 20 buah kampung. Semuanya sudah saya kenal, jalan-jalannya, keadaannya, dan penduduknya. Orangnya juga sudah kenal saya.

(Six months later, the duty of selling confections was growing. I was brought up to be a petty trader. Kalumpang is a district comprising more than 20 villages. I knew them all, the roads, the conditions, the people. The people too, knew me.)

(Arena Wati, 1991: 26).

Nah, sebelum umur sepuluh tahun saya sudah jadi saudagar dan pedagang kecil. Sebelah pagi menjual kuih yang dibuat oleh emak. Tengah hari hingga larut petang, saya membeli telur. Saya monopoli perdagangan ini 
di seluruh mukim Kalumpang. Pada setiap rumah saya ikat pajak dengan hasil telur ayam dan telur itik. Saya gilirkan waktu untuk pergi mengambil telur. Mulanya kandar atau pikul sendiri. Tetapi kerana tidak kuat memikul sendiri, akhirnya saya mengaji sesama kanak-kanak. Maka mulailah saya mempunyai kuli. Harga pajak telur ayam ialah dua biji satu sen, manakala telur itik, tiga biji satu benggol (dua sen setengah).

(Well, by the age of $10 \mathrm{I}$ had become a merchant and petty trader. In the morning selling confections made by mother. In the afternoon till late evening, I bought eggs. I had the monopoly of the trade in the whole district of Kalumpang. I contracted every household for their chicken and duck eggs. I allocated time to collect the eggs. In the beginning I used a kandar $^{1}$ or carried them myself. But as I was not quite strong enough to carry them myself, I started paying other children to do it. Thus I began to employ labourers. The cost of contracting a chicken egg was one sen for two eggs, whereas it was two and a half sen for a set of three duck eggs.)

(Arena Wati, 1999:28-29).

In the life of Arena Wati, the world of sailing started with his father who took him along whenever he sailed to nearby destinations. His sailing and trading experience continued until, from an ordinary sailor, he became a captain. After a long period of sailing Arena Wati was appointed nakhoda (captain), expressed in the Makassar and Bugis dialect as, "ana'koda". Besides nakhoda, the term juragan (shipowner) is also used to refer to such a person. What is a nakhoda or juragan? According to Kamus Istilah Teknik Perkapalan (1985:46), dictionary of shipping terms, "he is the captain or leader of a traditional sail boat or trading ship". The leader referred to here leads in all business matters related to a ship (referring to a medium-sized or large sail boat) and its cargo (Mawarti and Notosusanto, 2008:128). The captain's position can be the highest in a sailing ship. This would be true if the captain owns the sail boat that he navigates. However if the owner is someone else, the captain is at the second highest position after the owner of the ship in question. This is so since in maritime trading there is no definitive difference between the one who executes trade and the person who sails the ship, just as there is no clear-cut difference between the sail-boat owner, the captain and the trader because at times they are all the same individual. Nevertheless some ship owners also assigned their ship along with the cargo to be traded to the captain, to be executed on a basis of profit-sharing (Mawarti and Notosusanto, 2008:127). In the hierarchy of, or positions in, any voyage the captain plays a major role. The captain 
and trader may be the same individual if the sail-boat owner is the captain and the cargo to be traded belongs to him. However, the ship owner may assign his ship to a captain for the purpose of trade based on profit-sharing to the captain and his crew.

The captain of a large trading ship usually had numerous crew members to assist him on voyages. The number of the crew depended on the size of a ship or boat. For example a large sailing ship would have a crew of between 10 to 20 (Mawarti and Notosusanto, 2008:128). The captain would be assisted in his duties by a helmsman, chief and minor navigator, that is, the mainstay of any voyage. The ship craftsmen comprised chief craftsmen, left and right craftsmen, box and centre craftsmen. Whereas at the lowest level were the minor crew headed by a serang-headman of the sailors.

The helmsman was responsible for the rudder, that is, the person who would steer the ship on a certain course. The helmsman had to know the shipping line and was in charge of steering the ship. His position was behind the leadsman. A leadsman was responsible for the anchor and to watch that the ship did not run against a coral or touch a sandbar. For this reason his position was at the direction at which the ship was moving. At times there were two leadsmen (Mawarti and Notosusanto, 2008: 128).

The captain had an important role on a sailing ship because it was he who organised and set in motion all components in a sailing ship, from the captain to his lowest level of his crew. Was the captain's only role to ensure the sail boat sailed safely to its destination? According to Ammarell:

... it is he who is ultimately responsible for selecting and supervising the crew, negotiating for cargoes, maintaining the ship, and safely and efficiently navigating the ship.

(Ammarell, 1999:202).

The quotation explains that apart from the responsibilities of steering the ship, the captain's role also included trading.

The emphasis on a captain's role in the maritime tradition of Nusantara was on navigating the sailing ship, and trading. Furthermore, Ammarell adds that, roughly half of the duties of the captain was to trade and the rest was related to navigation of the sailing ship. In the context of sailors of Makassar like Arena Wati, the ship referred to were certain types sailing ships, that is, the schooner, the padewakang and the pinisi.

The trade carried out by a captain depended on the cargo it carried. It involved taking cargo to the seller or accepting cargo to be taken to a specified 
destination. On arrival at a harbour, the captain would order his crew to unload the goods that had been ordered, as well as look for other cargo to be taken to a different destination. Some of the larger sail boats used two captains for long voyages, that is, one at sea and the other on land. The sea captain had the specific task of attending to matters related to sailing, and the land captain was in charge of administering cargo. The land captain also recorded all output and sales as well as other matters that needed attention while on land (Mawarti and Notosusanto, 2008:128).

However, it was also usual for sailing ships on long voyages to have only one captain, namely the sea captain. In such cases the captain would attend to both matters, that is, on land relating to goods for trading and at sea for sailing matters. This depended on the capability of the captain, that is, whether or not he could do both jobs.

\section{CAPTAIN AS TRADER}

Arena Wati's sailing expertise was so well-recognised that he was entrusted with the duty of captain of a schooner named Sorga Bone, at the age of 171/2 in 1943 (Arena Wati, 1991:71). Besides he was captain of several sailing ships such as the Sorga Madinah. As a trader the captain's duty was to obtain cargo to be loaded on his ship and sent to other places. His sailing ship docked at the harbours of Cirebon, Semarang, Jakarta and Tegal in Java, with cargoes of merchandise such as produce of copra, salt, salted fish, sugar, dried chilly and rice which were sent to Palembang, Pontianak and Singapore. In other words, the captain had to be an accomplished trader. However Arena Wati's involvement in maritime trade was not the same as before and after western colonization which was focussed mostly on the spice trade. It has been mentioned that Arena Wati's skills in the world of trade surfaced when he was a child, and this was inherited from his father and grandfather, both held in high regard as sailors and traders of Kalumpang. Knowledge of the world of trade was essential for a captain in order to acquire cargo. Arena Wati became trusted among traders to deliver merchandise at particular ports owing to his diverse abilities. In his words:

Sayalah yang termuda di antara 40 orang nakhoda itu. Tetapi pada anggapan mereka Sorga Bone yang paling laju, dan saya fasih berbahasa Melayu dan mereka lihat saya tahan lasak menghadapi Jepun; maka dengan sukarela mereka sepakat melantik saya sebagai ketua untuk menjalankan urusan muatan dan destinasi. Dan yang terpenting sekali urusan membeli kain layar, tali-temali dan seribu satu macam peralatan perahu, yang waktu itu serba bercatu di Syonan-to. 
(Among 40 captains I was the youngest. But in their view Sorga Bone was the fastest, I spoke fluent Malay, and they saw that I was tough in dealing with the Japanese; so, voluntarily there was a consensus to appoint me to take charge of the loading and matters of destination. And most importantly, for purchasing the sails, riggings and a thousand and one sorts of boat equipment, all of which were at the time, highly rationed items in Syonan-to.)

(Arena Wati, 1991:73).

Arena Wati's sailing expertise also attracted the interest of a Chinese trader who wished to engage his services as a navigator in taking his merchandise to a particular location. Besides that, he was trusted and loved by Then $\mathrm{Bu}$ Phon from Sai Hoi Thung company:

Then Bu Phon tahu derita batin saya. Tetapi dia yakin saya akan selamat dalam keadaan begitu. Hubungan kami bukan lagi sebagai majikan dan kuli. Bukan lagi sebagai majikan dengan kuli yang mempunyai cita-cita dan kemampuan bertindak. Bukan lagi saudagar dengan rakan kongsi; tetapi anggapannya kian mendalam terhadap diri saya, sebagai anak bekas temannya zaman dahulu. Maka tidak hairanlah, kalau dia selalu memperlihatkan sikapnya kepada saya sebagai seorang ayah kepada anak.

(Then Bu Phon knew my internal conflict. But he was confident I would be safe in those circumstances. Our connection was no longer that of employer and worker. No longer employer and worker who had aspirations and the ability to act. No longer merchant and partner; rather, his opinion of me was getting increasingly deeper, as the son of an old friend from the past. Therefore it was no surprise that towards me his attitude was always that of a father to a son.)

In fact he also succeeded in winning the hearts of the Japanese in delivering goods. His discipline in observance of religious rituals made him fearless in trying his luck with sailing even though the Japanese forced him to sail to locations where other ships were not willing to go (Arena Wati, 1991:73).

Apart from obtaining cargo, a trading captain also has the duty to keep a record of goods bought or traded and of income and expenditure. Before he became a captain Arena Wati was a clerk on the Sorga Bone in charge of loading cargo and all sorts of other matters at port. This was because the previous captain of Sorga Bone, Daeng Massuk, was illiterate and did not know the palm-leaf writings in the language of Makassar. During that time 
Arena Wati learnt the ins and outs of matters relating to cargo, port matters and the labourer system at Java Harbour from his father's cousin, Daeng Nanjang, who was the pilot on the Sorga Bone. However, Daeng Nanjang's knowledge was based only on the time of the Dutch whereas at that time Japan had gained control of the harbour in Java where the system was more or less dependent upon the approval of the Japanese.

Besides his efficiency in obtaining cargo, Arena Wati was also competent in keeping accounts of the distribution of income from trade which was carried out on a profit-sharing basis with sailors and crew:

Sistem agihan pembahagian laba antara pemilik perahu dengan kelasi menurut cara Makassar iaitu satu pertiga milik tuan punya perahu dan dua pertiga milik kelasi. Agihan milik kelasi ini terdiri daripada semua kelasi dan nakhodanya, ditambah lagi dengan bayaran faedah menggunakan beberapa alat yang disediakan oleh tuan punya perahu, iaitu sampan pendarat iaitu dikira satu kelasi; periuk dapur dan pinggan mangkuk satu kelasi, seluruh guci dan dram tempat air minum satu kelasi; modal satu kelasi. Agihan kepada empat jenis bahan kemudahan ini menjadi hak pemilik perahu. Manakala nakhoda, jurumudi dan jurubatu, di samping dapat agihan masing-masing satu kelasi, mereka juga dapat bayaran sagu hati sebagai balasan jasa dari pemilik perahu. Belanja tanggungan kelasi ialah barang makanan sahaja manakala belanja tanggungan perahu, ialah peralatan perahu itu sendiri. Oleh itu, seluruh laba kasar, hanya ditolak belanja labuh batu, sebelum dibuat agihan.

(The Makassar system of profit-sharing distribution between the owner of the boat and sailors was, one-third belonged to the boat owner and two-thirds to the sailors. The distribution of the sailors' share, consisting of all the sailors and the captain, included interest calculated according to the use of various facilities provided by the boat owner. That is, the sampan used for landing was considered as one sailor; kitchen utensils such as crockery and cutlery, as one sailor; all pitchers and water container drums, one sailor; capital, one sailor. The distribution of these four types of facilities was the boat owner's share. Whereas the captain, helmsman and leadsman, besides receiving the individual shares of each crew, also received a compensation as reward for services from the boat owner. The sailors' only expenditure was food, whereas the rest of the expenditure for upkeep was on the boat, that is, they had facilities on the boat. Thus, of the overall profits, only expenditure for labuh batu (a kind of tax collected at a certain point along a river) was deducted before its distribution.)

(Arena Wati, 1991: 20). 
In the maritime trade of the Indonesian islands, a captain who did not own a boat was not paid a salary but instead, his source of income depended on the distribution system based on profit-sharing. Arena Wati was clearly a captain who knew the ins and outs of trading and the systematic distribution of profits. In Arena Wati's words:

... kami pelaut turun-temurun dari Sulawasi tidak pernah mengenal dan tidak bergantung pada hidup makan gaji. Pendapatan kami dikira dari agihan laba dari setiap satu pelayaran. Oleh sebab itu kami berjiwa untung rugi. Kami berlayar dengan konsep niaga.

(...we, who have been sailors from Sulawesi for generations have never known nor depended on a salary for sustenance. Our income was calculated from the profits of each voyage. For this reason profit and loss was in our soul. We sailed on the concept of business.)

(Arena Wati, 1991:75)

Sistem agihan kapal Bugis jauh lebih sederhana iaitu seluruh laba dibahagi dua. Separuh kepada pemilik perahu, dan separuh lagi kepada kelasi. Tetapi modal, sampan pendarat, guci, dram tempat air minuman, dapur dengan seluruh peralatannya jadi tanggungan perahu. Bahagian nakhoda juga sama rata dengan kelasi tetapi nakhoda, jurumudi dan jurubatu dapat bayaran tambahan dari pemilik perahu.

(The system of distribution on Bugis ships was for more simple, that is, the whole profit was divided into two. Half to the boat owner, and another half to the sailor. But capital, landing sampan, pitchers, drinking water-drums, kitchen ware and all the facilities were borne by the boat. The captain's share was just the same as the sailors' but the captain, pilot, and leadsman got additional payments from the boat owner.)

(Arena Wati, 1991: 20-21)

In World War II, with the Japananese Occupation of Southeast Asia the profit-sharing system, inherited for generations, changed. Around May 1943, the Sorga Bone along with 39 other schooners were forced to shift from permanent harbours at the Javanese islands to Singapore. In Singapore, the Japanese controlled the sailing and cargo with systems which were determined and owned by them:

Kami belayar dengan konsep niaga. Tetapi ketika Jepun menguasai pelayaran kami. Semua muatan jadi ditentukan oleh Jepun dan akhirnya seтиa muatan 
milik Jepun. Ketika muatan dimonopoli oleh orang Jepun- walaupun pelaksana muatan melalui saudagar-saudagar Cina-kami hanya menerima upah menurut sewa pengangkutan sahaja. kadar sewa yang ditentukan oleh Jepun terlalu murah kalau dibanding dengan kadar yang wajar dalam dunia perniagaan.

(We sailed on the concept of business. But when the Japanese controlled our voyages, all the cargo was determined and ultimately, owned by them. With Japanese monopoly of cargo-implemented through Chinese merchants-we were only paid the rental from transportation. The rate fixed by the Japanese was much too low compared with the rightful rate in the business world.)

(Arena Wati, 1991:75).

All matters and types of cargo and the destination of cargo were so closely controlled by the Japanese that as a captain, he was unable to decline when ordered to take goods to a particular place. For example, Arena Wati was ordered to take granulated sugar to Palembang. The low rental fixed by the Japanese also forced Arena Wati and his crew to sell contraband goods such as anti-malarial quinine pills or medicine, stones and gems, Singer sewing machines and used dinner suit coats.

Kami belayar dengan konsep niaga. Tetapi ketika Jepun menguasai pelayaran kami. Sетиа muatan jadi ditentukan oleh Jepun dan akhirnya semua muatan milik Jepun. Ketika muatan dimonopoli oleh orang Jepun - walaupun pelaksana muatan melalui saudagar-saudagar Cina-kami hanya menerima upah menurut sewa pengangkutan sahaja. Kadar sewa yang ditentukan oleh Jepun terlalu murah kalau dibanding dengan kadar yang wajar dalam dunia perniagaan. Upah ini tidak akan cukup walaupun setakat menyara hidup, layar dan tali-temali kami. Oleh sebab itu kami berniaga barang-barang kecil yang mahal harganya. Kami tahu pil kuinin (antimalaria) terlalu mahal di Singapura, Kalimantan dan Sumatera yang harganya dikatakan setimbang emas. Tetapi barang itu banyak dan terlalu murah di Jawa. Barang itu terlarang. Tetapi kami tahu jalannya yang mesti dilakukan, sumber dan orang perantaraan yang akan menyerahkan kepada kami, dan pasarannya. Kami juga tahu bahawa lelaki golongan priayi di Jawa amat tergila-gila dengan batu-batu permata; dan di Puntianak, Pemangkat dan Sambas di Kalimatan Barat; Batu-batu Zamrud dan Delima, dapat kami beli dengan mudah dan dengan harga yang murah daripada orang-orang tertentu. Dari mana sumbernya, itu bukan urusan kami

...Kami juga mengetahui bahawa jarum mesin jahit Singer ketika itu terlalu banyak dan sangat murah harganya di Singapura. Tetapi barang itu kalau 
tiba ke Jawa harganya akan melebihi harga emas. Jalan keluar masuk ke pelabuhan di Jawa. Setiap orang diperiksa. Tetapi bungkusan jarum mesin jahit kelihatan terlalu kecil dan tipis, kalau hanya dibungkus dalam satu kodi. Bungkusan itu mudah disimpan dalam lipatan kali seluar, pada lipatan kolar dada baju kot. Setiap kali melintasi pintu pelabuhan. Sekurang-kurangnya 200 kodi jarum mesin jahit boleh dibawa keluar.

(This payment was insufficient to support us, our sails and riggings. Because of this we traded in small but expensive goods. We knew that that the cost of anti-malarial quinine pills were equal to its weight in gold in Singapore, Kalimantan and Sumatra. However it was in plentiful supply and extremely cheap in Java. It was prohibited goods. But we knew ways around it, the source and go-betweens who would give it to us, and the markets. We also knew that the priayi in Java were mad about stones and gems; and in Pontianak, Pemangkat and Sambas in West Kalimantan, we could buy emeralds and rubies cheaply from certain people. Where it came from, was not our concern.

We also knew that "Singer" sewing machine needles at the time were extremely plentiful and cheap in Singapore. But when they arrived at Java the cost would be more than that of gold. The way in and out of the port was in Java. Everyone was searched. But a packet of sewing machine needles seemed much too small and flat if it was wrapped in $k o d i{ }^{2}$ The packets were easy to stuff into the folds of trousers, in the folds of the breast pocket of collars of dinner suits. Each time the entrance to the port was crossed at least 200 kodi of sewing machine needles could be taken out.)

(Arena Wati, 1991:75).

Also, during the Japanese Occupation there was no more free trade. For example, in order to obtain a supply of rice, a letter of permission was required beforehand to get ration, and this compelled Arena Wati to source it through Chinese blackmarket merchants.

\section{CAPTAIN AS NAVIGATOR}

Aside from the function of trader, the captain also had a role in administering and heading matters related to the ship or sail-boat. The expertise required to take a boat or ship from one place to another is known as navigation. Knowledge of navigation is related to determining the position and direction of a ship (Kamus Istilah Teknik Perkapalan, 1985: 89). Most captains acquired skills in sailing from their maritime environment. This included Arena Wati. A good captain should have a knowledge of the sea in various aspects. For 
him, the sea becomes a place of life and death. The sea is an intimate part of Arena Wati's background. A good navigator has to keep a keen eye on prior preparations for sailing. Apart from food supplies, it is important to pay attention to ship supplies before starting on a voyage to provide for any contingencies on a voyage, throughout its duration.

Arena Wati's greatness as a captain with a knowledge of navigation enabled him to equip his sailing ship to face all weather conditions. In one incident Arena Wati, was to deliver steel bars for building construction to Ambon, but was prevented by weather conditions of the Southeast monsoon season, when the Wowoni Straits could not be crossed. No sailing ship captain had the courage to do it. However one sailing ship called "Sorga Madinah" headed by Daeng Limbung who was attracted by the generous payment for delivering the cargo was willing to do it on condition that Arena Wati was captain of the ship. Arena Wati accepted the challenge with confidence and made all necessary preparations to equip the "Sorga Madinah" for rough seas.

Setelah dimuati saya mengubah suai layar, tali-temali tegak condong tiang belakang, dan mengganti tali kawat keluli temberangnya dengan keluli bangunan konkrit. Orang-orang di pelabuhan tercengang melihat perbuatan kami, menggunakan batang besi sebagai tiang temberang. Juga orang tercengang kerana saya mahu belayar ke Ambon pada musim tenggara putih. Tetapi bukankah Abdul Fatah dan ayah saya sendiri dengan pandewakang pelari Samalewaya sudah melakukan lebih daripada itu? kenapa cucunya tidak? Ini satu cabaran besar.

(Once the cargo was loaded I altered the sails, the riggings, the standing of the main pole and back pole, and replaced the steel-rope type riggings with steel bars of concrete buildings. People at the port stood gawking at our actions, using iron bars for rigging poles. People were also gawking because I wanted to sail to Ambon in the Southeast monsoon season. But wasn't it Abdul Fatah and my own father on the sail boat "pandewakang Samalewaya" who had done more than that? Why not his grandson? This was a big challange.)

(Arena Wati, 1991: 214).

...kemampuan kami menyampaikan barang itu ke Ambon merupakan kemenangan politik Gabenor Laturharhari di Maluku. Kemudian kemampuan Sorga Madinah mencabar nakhoda-nakhoda lainnya. Pada bulan-bulan berikutnya, ketika angin barat sudah tiba, ramai yang mengambil muatan ini, sehingga habis semuannya. Dr. Latuharhari, Gabenor Maluku, dapat membina kembali Maluku, dapat membina kembali kota Ambon. 
(... our ability to deliver the goods to Ambon was a political victory for Governer Laturharhari of Maluku. Besides, Sorga Madinah challenged other captains. In the months that followed, when the west winds arrived, many took on the cargo, until it was all completed. Dr. Latuharhari, Governor of Maluku, was able to rebuild Maluku, able to rebuild the city of Ambon.)

(Arena Wati, 1991: 215)

Arena Wati was determined to sail across the turbulent straits armed with a seafaring spirit, just like his late grandfather and father. As a respected captain Arena Wati was responsible for selecting and supervising his crew. This was an important duty because ingenuity and skill in selection would determine the success or failure of a voyage. Arena Wati's authority in selecting his crew surfaced in three ships that he headed as captain. On the Sorga Bone he was appointed captain of the crew that was already there. However when it was delivered to the owner's son in Singapore, he chose Tura and Palopo, that is, people entrusted to deliver the ship safely to its owner, although initially Tura did not consent because he did not wish to be separated from Arena Wati. And in a stern voice, he ordered those of his crew who had wives in Makassar to return, whereas only the bachelors were selected to continue on with him (Arena Wati, 1991:134). In another place, when he was asked by Then Bu Phoon to be leader in the wooden boat Deckhand which had a capacity of 80 tons, he agreed on condition that he be allowed to determine his own crew:

Sam Hoy Thung sudah dapat membeli kapal kayu, muatan 80 tan, enjin diesel yang boleh melarikan kapal itu selaju 18 knot. Saya memilih orang Sulawesi sendiri menjadi kelasi dan jurumudinya. Orang Hailan bertugas di enjin. Kami tidak perlu ramai petugas untuk kapal 80 tan ini. Malah kami tidak perlu kapten rasmi. Kami belayar tanpa dokumen pelayaran. Kami hanya menggunakan tenaga seorang chief engineer, seorang pembantunya dan seorang tukang minyak. Deckhand hanya dua orang kelasi yang sekali gus jurumudi dan tukang masak. Kami cuma enam orang.

(Sam Hoy Thung was able to buy wood, a cargo of 80 tons, and a diesel engine that could run the ship at 18 knots. I selected people from Sulawesi as sailors and pilots. Someone from Hailan was on duty at the engine. We did not need many people on duty for this 80 ton ship. In fact we did not need an official captain. We sailed without sailing documents. We only used the services of a Chief Engineer, an assistant to him and an oiler. There 
were only two deckhand sailors who were also pilots and cooks. We were only six people.)

(Arena Wati, 1991:169)

Arena Wati did the same thing when he was asked to be the captain on the Sorga Madinah to deliver iron and steel bars to Ambon. In other words he showed he was capable of fulfilling the conditions of a captain to select the right crew with a clear goal, as Ammarell mentioned, about the responsibilities of a captain.

A captain should also have good relations with his crew. They should be united and helpful and considerate. Arena Wati had good relations with his crew. Although he was appointed captain at the young age of 17, his relationship with older sailors was very close. He states this himself:

Betapa pun juga bangganya sebagai nakhoda muda yang berkuasa penuh pada urusan darat dan laut, tetapi saya perlu berhati-hati menghadapi kelasi-kelasi yang telah tua, dan juga yang telah jauh lebih dewasa daripada saya. Malah dari segi pengalaman samudera, mereka umumnya lebih matang dari saya sendiri. Pengalaman saya yang baru, hanya lebih satu tahun dengan perahu skuner seperti Sorga Bone ini. Masih terlalu mentah kalau dibandingkan dengan jurumudi, jurubatu malah para kelasi Sorga Bone sendiri.

(No matter how proud I felt as a young captain with full powers over land and sea matters, I had to be cautious in handling the elderly sailors, and even those who were far older than me. In fact in the aspect of experience of the seas, they were generally more mature than I was. My new experience was only a little more than a year, with a schooner like the Sorga Bone. That was still very green compared to the captain, leadsman and even the sailors on the Sorga Bone.)

(Arena Wati, 1991:71-72)

In addition, according to Arena Wati they obeyed him with respect because of his father's and grandfather's reputation as expert seafarers and as outstanding captains over generations.

The relation between captain and crew of this nature in the Bugis community, which also applies to the people of Makassar, is associated with the practice known as siri'.

In Ammarell's words:

It is however, not enough to know how to navigate; to be able to command 
the respect of his crew, a captain must display the moral quality of siri' "dignity" and "honor".

(Ammarell, 1999:212).

A strong sense of honor and dignity, embodied in the Bugis term siri', is also requisite to attraction of cargoes and retention of a loyal and hard-working crew. It is these qualities that, in the minds of the Bugis, characterize the most efficacious and, thereby, most respected navigators.

(Ammarell, 1999:217).

This practice of siri' is apparent not only with regard to the connection between captain and crew but also to trader and customer. The practice arose out of the interaction of ship captain and crew having a mutual respect between them. The mutual respect is shown by being mindful of each other's dignity or disgrace. For instance, if a captain has to criticise the mistake of his sailor, he cannot do so in public, and vice versa. This concept is almost the same as the sailing ethic originating from the philosophy of "I Lolobayo". Arena Wati was taught ever since he was a child the ethics, mystique and practice of sailing from the source of "I Lolobayo":

...sebagai nakhoda ayah mendalami ilmu dan hukum pelayaran dari sumber I Lolo Bayo.

(... as a captain father investigated the knowledge and laws of sailing from the source of I Lolo Bayo.)

(Arena Wati, 1991:23)

...di samping itu diajarkan juga mengerjakan etiket, mistik dan praktik ilmu pelayaran dari sumber I Lolobayo...

(Many seafarers, but not all, in my country were knowledgeable of the content of "I Lolobayo" which was never written down in black and white.)

(Arena Wati, 1991:194)

It was this ethic of sailing observed by Arena Wati that made him respected among his crew.

Through the practice of siri' and the philosophy of I Lolobayo, Arena Wati was prepared emotionally and spiritually to serve as a captain on the challenging seas. In addition, mental preparation was essential to a being a captain in critical conditions such as being challenged by fierce waves or the 
colonizer. Mental strength was essential, as the captain should be smart in strategizing to ensure that his ship reached its intended destination safely. As a captain Arena Wati was very smart in strategizing his voyage, particularly in avoiding blockades of Dutch hunter ships and air attacks by Japanese forces. In his leadership of the Deckhand, he succeeded in overcoming a blockade. He was so skillful in strategising voyages that to him it was considered playing cat-and-mouse with Dutch hunter ships who organized blockades. His sailing strategy may be seen from the following extract:

Surat khabarStraits Times dan juga Singapura Standard ketika itu setiap hari keluarannya lengkap keterangan tentang air pasang surut. Seluruh letak batu karang di Selat Melaka hingga ke Jawa sudah saya hafal dan tahu dalamnya air ketika pasang penuh atau surut timpas. Dalam teori pelayaran, batu karang untuk dijauhi tapi bagi saya, batu karang adalah digunakan dan dilalui.Pengetahuan dari pengalaman ini saya gunakan untuk memotong carta menggariskan jalur pelayaran di atas peta, hari bulan dan jam perjalanan, untuk semua laluan dan semua destinasi.

(The Straits Times and also the Singapore Standard newspapers at the time provided daily information on the high and low tide. I had memorized the location of every coral reef in the Malacca Straits up to Java, and I knew the depth of the water at the times of high tide or low tide. In the theory of sailing, coral reefs were to be avoided but for me, they were used and forded. I used this knowledge, based on experience, to draw charts, to map the sail routes, to provide the date and time of departure for all passageways and destinations.)

(Arena Wati, 1991:169)

Owing to his sailing strategy his ship was held in awe and praised by other captains and in fact, in one month his ship made four trips to Tungkal where his passage was blockaded by Dutch hunter ships. In one incident, Arena Wati devised a strategy to avoid capture by the Dutch colonizers by ordering his crew to wear long black stockings and long black gloves, and everyone had to keep a piece of glass and pen-knife in the folds of their work-clothes throughout the voyage. He also told them to store money in the folds as well. Poles of buluh betung ${ }^{3}$ were cut to 10 feet each. When the destroyer came near, they jumped into the water with the bamboo poles. The black stockings and gloves caused their palms and the soles of their feet to lose their paleness in the sea. This saved them from attack by sharks. With the help of two bamboo poles each they were able to float safely by holding 
the poles under their arms until they reached a coral reef and waited for the low tide. The next day, when the tide was low and the reef could be seen, the pen-knife was used to shell oysters for food. On the second day they used the small glass piece to signal fishing boats that were sailing back to Singapore (Arena Wati, 1991:170-71). In other words, although it seems like a primitive strategy, it was practical and creative for Arena Wati.

Faced with a Japanese air raid, Arena Wati ordered the sailing ship Sorga Bone to be floated downstream without sails. He also ordered the masts of the centre pole and back pole of the Sorga Bone to be lowered to escape the air attack and, with a large number of nipah palm leaves, covered up the ship so that it was invisible from above to the allied forces (Arena Wati, 1991:82).

In addition to being an ingenious sailing strategist Arena Wati was also ingenious in moving the sails to suit the wind directions that would take them safely to their destination. He altered the sails of a Chinese junk named Selamat Untung. This is clearly reflected in the extract:

Wangkang ini kami cuba pada beberapa jenis keadaan angin dan ombak. Saya dapati wangkang ini kurang peka menyahut kemudi, terlalu tumpul di mata angin, dan mudah dibuli arus. Dengan serta-merta saya tahu, bahawa struktur badannya yang menyebabkan ini. Tapi kami tidak ada hak untuk mengubah bentuk badannya. Lalu kami ubah suai layarnya. Layar itu terlalu gemuk, berbentuk sayap keluang, tulang-tulangnya diperbuat daripada batang bakau yang diraba bersambung-sambung. Layar ini kami buka, kami tarik ke arah tiang, lalu menjahitnya kembali, dan meninggalkan sedikit gelembung di puncak luar. Layarini lebih ramping dan papat kelihatannya dan gelembung di puncak luar itu padat tegang menahan angin. Kami ubah sedikit tiang agungnya, lebih condong ke hadapan. Kerja mengubah tiang ini agak lama, kerana tiang ini turus santak ke lunas. Oleh sebab itu kami bongkar sedikit geladak dan rusuk geladak dan tajuk pangkal tiangnya.

Kami cuba kembali, dan kami dapati Selamat Untung sudah mampu naik lebih tajam ke mata angin dan lajunya bertambah. Tapi belum mampu melepaskan dirinya dari cengkaman arus.

(We tried out this Chinese Junk in several wind and wave conditions. I found the Junk to be insensitive to piloting, too blunt to wind directions, easily bullied by currents. Immediately I knew that the structure of its frame was the cause of this. But we did not have the right to alter the shape of its frame. So we altered its sails. The sails were too thick, like the wings of a flying fox, its veins were made of mangrove trunks that were interconnected. We removed this sail, and pulling it in the direction of the mast, sewed it 
back, leaving a little swelling at the outer tip. This sail was slimmer and looked strong and the swelling at the outer tip was caused by the wind being blocked. We moved the main mast a little, leaning more to the front. The job of adjusting the leaning pole took a long time, because it stood straight down to the keel. Therefore we broke a little the deck, the deck beam and upper part of the pole.

We tried it out again, and found the Selamat Untung was able to rise more sharply to compass point and its speed increased. However it was still unable to evade the hold of currents.)

(Arena Wati, 1991:134-135)

Arena Wati also demonstrated ingenuity in adjusting the sails when he lead the Sorga Madinah. He not only adjusted the sail but also the standing and leaning of the main and back poles and replacing the riggings with better material to handle the challenging season of the Southeast monsoons. In fact, the Southeast monsoon season was feared by sailors, as expressed by Arena Wati in the following extract:

Memang berat. Saya akui betapa kejamnya dan ganasnya ombak dan angin tenggara putih. Tetapi Sorga Madinah dengan layar kanvas putihnya yang baru, dan kelengkapan yang serba baru dan kukuh, serta disiplin kelasi yang bermoto kumpulanna barang parrekna atau kumpulan dari kumpulan orang-orang yang tidak peduli apa pun, dapat menunaikan hasrat pemerintah untuk menyampaikan muatan itu ke Ambon.

(It was certainly serious. I would aknowledge the harshness and ferocity of the southeast waves and winds. But Sorga Madinah with its new white canvas sails and all-new and firm fittings, along with the discipline of the crew with the motto kumpulanna barang parrekna, or, the group among groups who don't give a toss, would be able to fulfil the requirements of the rulers to deliver the cargo to Ambon.)

(Arena Wati, 1991:214)

With a strategy and piloting skills, this was the spirit that facilitated success in delivering iron bars for the rulers at Ambon. The ability of Sorga Madinah to successfully overcome the threat of the Southeast monsoons had challenged other captains. Until in the following months, when the west winds arrived, they dared to take the cargo of iron and steel bars to Ambon.

One important aspect of the captain in the Nusantara tradition was the ability to navigate with the guidance of natural signals such as winds, waves, 
stars, currents and so on. This tradition has been mentioned by Shaffer in the following quotation from Keith Taylor (1976):

The Malay sailors were highly skilled navigators, sailing over the oceans for thousands of miles without a compass or written charts. They navigated by the winds and the stars, by the shape and color of the clouds, by the color of the water, and by swell and wave patterns on the ocean's surface. They could locate an island when they were still like 30 miles from its shores by analyzing the behavior of various birds, the animal and the plant life in the water, and the patterns of swell and waves .... This complex knowledge was passed on orally from generation to generation.

(Shaffer, 1996:11-12)

The term, Malay sailors that Shaffer mentions refers to the Malays of Nusantara, which includes the people of Makassar and the Bugis.

In the context of navigation, being guided by natural elements is called celestial navigation. In Arena Wati's memoir which is being studied there is not much explanation of incidents on his voyages relating to celestial navigation, that is, the knowledge of sailing with the guidance of natural elements such as the waves, the stars and the winds in his memoir. However he has mentioned that he learnt these natural elements as a child:

Sebagai anak yang paling tua (hidup) saya dapat perhatian besar daripada keluarga ayah dan emak saya. Ayah saya sendiri yang mengajar mengaji Quran sehingga khatam. Di samping itu diajarkan juga etiket, mistik dan praktik ilmu pelayaran dari sumber I Lolobayo. Dalam usia menjelang lima tahun, sebelum saya bersunat saya selalu dibawa belayar untukjarak dekat oleh ayah saya. Ketika itu diajar mengenal bintang dan namanya, musimnya berada di langit dan juga di mana letaknya langit. Saya diajar mengenal arus laut, mengenal pengaruh arus dan angin pada ombak di samudera, mengenal seluruh jenis angin di samudera, mengenal awam di langit yang membawa ribut dan membawa hujan. Dia diajar tentang segala peralatan perahu, jenisnya dan bagaimana membuatnya.

(As the oldest (living) child I received a lot of attention from my parents' family. My own father taught me how to recite the Qur'an till I reached khatam. ${ }^{4}$ In addition I was taught the etiquette, mysticism and practice of sailing sourced from I Lolobayo. At the age of about 5, before I was circumcised I was always taken sailing on short distances by my father. During that time I was taught to recognize the stars and their names, the seasons they were in the sky and also where their positions were in the sky. I was taught to be 
familiar with all the types of winds at sea, the clouds in the sky that brought storms and rain. I was taught about all the equipment of boats, the types and how they were made.)

(Arena Wati, 1991:25)

However in terms of practice, nothing is clearly mentioned. The memoir would be enhanced in the context of knowledge of sailing in Nusantara if Arena Wati had narrated in more detail on how celestial navigation skills were used and explained its importance in his success as a navigator.

\section{CONCLUSION}

Arena Wati was not only a successful literary laureate but also an accomplished captain of merchant ships fairly respected within the sailing and trading community of Makassar, South Sulawesi. His skill as a captain may be scrutinized with reference to his capabilities in carrying out two functions, that is, as a trader and as a navigator. The ability to perform these roles simultaneously has been the reason that the sailing ships under his stewardship were able to carry out trading activities impeccably and at the same time sail safely when departing from and arriving at the ports. Arena Wati's accomplishment as a captain is related to his family background which was steeped in the sailing and trading world. His geographical background contributed to his success too. Makassar, the place where he was born and raised was where the maritime world of Indonesia developed in terms of sailing and trading. The historical background of Dutch colonization and Japanese occupation coloured Arena Wati's activities as a captain. This has been well-narrated in the memoir, genre which he naturally utilized to display his capabilities as a successful captain much respected by friends and other traders. Arena Wati's success as a captain developed over a long period of time, and the memoir that he produced shows that he continued the maritime tradition of Nusantara of thousands of years, which he inherited from his family.

\section{NOTES}

1. A pole held on the shoulder with baskets at both ends.

2 An ancient Tamil measurement system, for counting and volume.

3 A species of large bamboo traditionally used to channel water.

4 Literally meaning, "the end", the term refers to completion of study/reading of the Qur'an. 


\section{REFERENCES}

Ammarell, Gene, 1999. Bugis Navigation. New Haven, Connecticut: Yale University Southeas Asia Studies.

Sogiono Paulus Andrianto and Sukotjo Mahardjo Wortono Asianto, 1985. Kamus Istilah Teknik Perkapalan. Jakarta: Pusat Pembinaan dan Perkembangan Bahasa, Jabatan Pendidikan dan Kebudayaan.

Arena Wati, 1991. Memoir Arena Wati: Enda Gulingku. Bangi: Universiti Kebangsaan Malaysia Press.

Marwati Djoened Poesponegoro and Nugroho Notosusanto, 2008. Sejarah Nasional Indonesia: Zaman Pertumbuhan dan Perkembangan Kerajaan Islam di Indonesia. Jakarta: Balai Pustaka.

Shaffer, Lynda Norene, 1996. Maritime Southeast Asia to 1500. Armonk New York: M. E. Sharpe.

Winslow, Donald J., 1995. Life-Writing. A Glossary of Terms in Biography, Autobiography, and Related Forms. Honolulu: University of Hawai'i Press.

(Translated by Lalita Sinha) 